\title{
Herd Management Practices and Their Association with Bulk Tank Somatic Cell Count on United States Dairy Operations
}

\author{
J. R. Wenz, ${ }^{* 1}$ S. M. Jensen, $\dagger$ J. E. Lombard, ${ }^{*} \dagger^{2}$ B. A. Wagner, $\dagger$ and R. P. Dinsmore ${ }^{\star}$ \\ *Integrated Livestock Management, Department of Clinical Sciences, Colorado State University, Fort Collins 80526 \\ †Centers for Epidemiology and Animal Health, Veterinary Services, Animal and Plant Health Inspection Service, USDA, Fort Collins, CO 80526
}

\begin{abstract}
The objective of this study was to evaluate associations between bulk tank somatic cell count (BTSCC) and herd management practices using data collected in the National Animal Health Monitoring System Dairy 2002 study. Twenty-six percent and $17.8 \%$ of 1,013 operations reported a BTSCC $<200,000$ cells $/ \mathrm{mL}$ and $>400,000$ cells $/ \mathrm{mL}$, respectively. Univariate analysis identified associations between management variables and BTSCC. The use of mattresses, sand, and newspaper as bedding were all associated with a lower BTSCC. Primary lactating cow housing facility, outside maternity housing area, flooring type cows walk or stand on, and use of automatic take-offs were also associated with BTSCC. Multivariate associations between management variables and BTSCC were determined by backward elimination ordinal logistic regression. The odds of an operation from the West, Midwest, and Northeast having a high BTSCC were lower than those from the Southeast. The odds of a higher BTSCC were 2 times greater for operations with a rolling herd average milk production $<9,090 \mathrm{~kg} /$ cow per year compared with those with $\geq 9,090 \mathrm{~kg} / \mathrm{cow}$ per year. Operations using composted manure were 2.9 times more likely to have a higher BTSCC than those not using composted manure. Finally, operations that reported not using a coliform mastitis vaccine were 1.7 times more likely to have a higher BTSCC than those using one. Future studies of the association between management practices and BTSCC should include an evaluation of the quality of management practice application and herd prevalence of contagious mastitis pathogens. Significant variables identified in this study dealt with housing, use of composted manure for bedding, and coliform mastitis vaccine use, suggesting the effect of environmental masti-
\end{abstract}

\footnotetext{
Received September 13, 2006.

Accepted April 16, 2007.

${ }^{1}$ Current address: Washington State University, Pullman, WA 99164.

${ }^{2}$ Corresponding author: jason.e.lombard@aphis.usda.gov
}

tis pathogens may be more influential on BTSCC than previously thought.

Key words: bulk tank somatic cell count, mastitis, management

\section{INTRODUCTION}

Bulk tank SCC (BTSCC) is a function of the prevalence of IMI within a dairy herd and is a key indicator of milk quality. The legal maximum BTSCC $(750,000$ cell $\mathrm{s} / \mathrm{mL}$ ) in the United States is higher than in other developed, dairy-exporting countries, and an evaluation of DHIA SCC data indicated $29 \%$ of herd test days had an SCC that exceeded 400,000 cells $/ \mathrm{mL}$, with the highest percentage of those test days (40\%) coming from the Southeast region of the country (Norman et al., 2000). If the US dairy industry is to remain competitive in the global market and maintain a positive image, further work is needed to lower BTSCC. Furthermore, many processors pay quality premiums for low-BTSCC milk, because there is a negative relationship between SCC and casein composition and shelf life of processed fluid milk (Ali et al., 1980; Ma et al., 1999). Ott and Novak (2001) demonstrated that herds with a BTSCC $<200,000$ cells/mL attained significantly more profit per cow than herds with a BTSCC $\geq 400,000$ cells $/ \mathrm{mL}$. These data indicate that it is worthwhile to implement costeffective management practices that reduce BTSCC.

Numerous studies have attempted to determine associations between management practices and BTSCC level or herd mean SCC. These studies were from Europe (Faye et al., 1997; Barkema et al., 1998) and different states and regions within the United States (Erskine et al., 1987; Hutton et al., 1990; Bartlett et al., 1992; Goodger et al., 1993; Norman et al., 2000; Rodrigues and Ruegg, 2005). However, there have been no recent reports of the association between producerreported management practices and BTSCC on a national level in the United States.

The objective of this study was to evaluate associations between BTSCC and herd management practices using data collected in the National Animal Health 
Monitoring System Dairy 2002 study representing the US dairy industry.

\section{MATERIALS AND METHODS}

States and operations selected to participate in the National Animal Health Monitoring System Dairy 2002 study were chosen to represent more than $80 \%$ of dairy cows and operations. Final selection included 21 states from 4 regions (West: California, Colorado, Idaho, New Mexico, Texas, and Washington; Midwest: Illinois, Indiana, Iowa, Michigan, Minnesota, Missouri, Ohio, and Wisconsin; Northeast: New York, Pennsylvania, and Vermont; Southeast: Florida, Kentucky, Tennessee, and Virginia).

Operations were randomly selected from a list sampling developed by the National Agricultural Statistics Service. Within each state, a stratified random sample was selected based on herd size. Operations with 1 or more milking cows were eligible for data collection via a questionnaire conducted by the National Agricultural Statistics Service enumerators from December 31, 2001, until February 12, 2002. Of the 3,876 eligible operations, 3,466 operations completed the initial questionnaire. Operations completing the initial questionnaire and milking 30 or more cows were invited to participate in an additional management questionnaire. A total of 1,013 operations completed the management questionnaire administered on-farm by a veterinary medical officer or animal health technician from February 25 to April 30, 2002. Additionally, producer-reported BTSCC was compared with a single milk sample collected at the time of the management questionnaire administration on a subset of 741 operations.

Producer-reported BTSCC was categorized as follows: $<200,000$ cells $/ \mathrm{mL}$, from 200,000 to 400,000 cells/ $\mathrm{mL}$, and $>400,000$ cell $\mathrm{s} / \mathrm{mL}$. Management variables plausibly associated with BTSCC were selected for univariate analysis. Univariate associations between a priori-selected management variables and BTSCC category were evaluated using the PROC CROSSTAB procedure in SUDAAN software (SUDAAN Release 9.0, Research Triangle Institute, Research Triangle Park, NC), which accounts for the sampling design weights. Ordinal variables present after univariate screening $(P$ $<0.25$ ) were subjected to oblique principal components cluster analysis using a maxeigen value $=1.0$. Adult herd size and rolling herd average (RHA) milk production variables were ordinal variables not included in the cluster analysis, because we wanted to examine their role as confounders and effect modifiers in the final model construction. Indicator variables chosen from each cluster for inclusion in the ordinal logistic regression model were those with the lowest $1-\mathrm{R}^{2}$ within each cluster, indicating they were most representative of the cluster. Backward elimination ordinal logistic regression using the PROC MULTILOG procedure in SUDAAN was used to create a final model, which included variables with a Wald-F $P \leq 0.05$. Ordinal logistic regression analysis assumes the effect of a variable is the same when comparing the lowest BTSCC group with the middle as comparing the middle with the highest group. This assumption may not be true, and the use of SUDAAN, which allowed analysis of weighted data, does not provide a proportional odds test to evaluate this assumption. Therefore, the final model obtained from SUDAAN was run without weighting in SAS, and the score test for the proportional odds assumption was evaluated.

\section{RESULTS}

Observations from 1,013 operations were included in the analysis. Twenty-six percent and $17.8 \%$ of operations reported a BTSCC $<200,000$ cells $/ \mathrm{mL}$ and $>400,000$ cells $/ \mathrm{mL}$, respectively. Of the 741 operations in which BTSCC was measured from collected milk samples, only $17.3 \%$ of operations reported a BTSCC lower than the measured BTSCC. Thirty-eight of 88 selected management-related variables were significant via weighted univariate screening and were eligible for inclusion in the final model (Table 1). Region of the country and adult herd size were associated with BTSCC $(P<0.001$; Table 1). Operations reporting $\geq 500$ adult cows were associated with a lower BTSCC and those in the Southeast with a higher BTSCC. A higher RHA milk production ( $\geq 9,090 \mathrm{~kg} / \mathrm{cow}$ per year) was associated with a lower BTSCC $(P<0.001)$. Cattle importation practice variables indicated $55.9 \%$ of operations imported new cattle during 2001, and there was no association with BTSCC. Weaned heifers were imported onto $9.6 \%$ and lactating cows onto $19.9 \%$ of operations. There was a tendency for an association between bringing weaned heifers onto the operation and a higher BTSCC $(P=0.059)$. Concrete flooring for cows to walk and stand on was reported by $69.3 \%$ of operations, and there was an association between flooring type and BTSCC $(P=0.045$; Table 1$)$.

Associations were also identified between bedding types used for lactating cows and BTSCC. Mattress use was reported by $22.7 \%$ of operations and was associated with a lower BTSCC $(P<0.001)$. Sand bedding use was reported by $21.5 \%$ of operations and was associated with a lower BTSCC $(P=0.022)$. Newspaper bedding use was reported by $7.2 \%$ of operations and was associated with a lower BTSCC $(P=0.006)$. Composted manure use was reported by only $6.1 \%$ of operations, and there was a tendency for an association with a higher 
Table 1. Herd management variables associated $(P<0.25)$ with bulk tank SCC (BTSCC) by univariate analysis of data from 1,013 dairies in 21 states

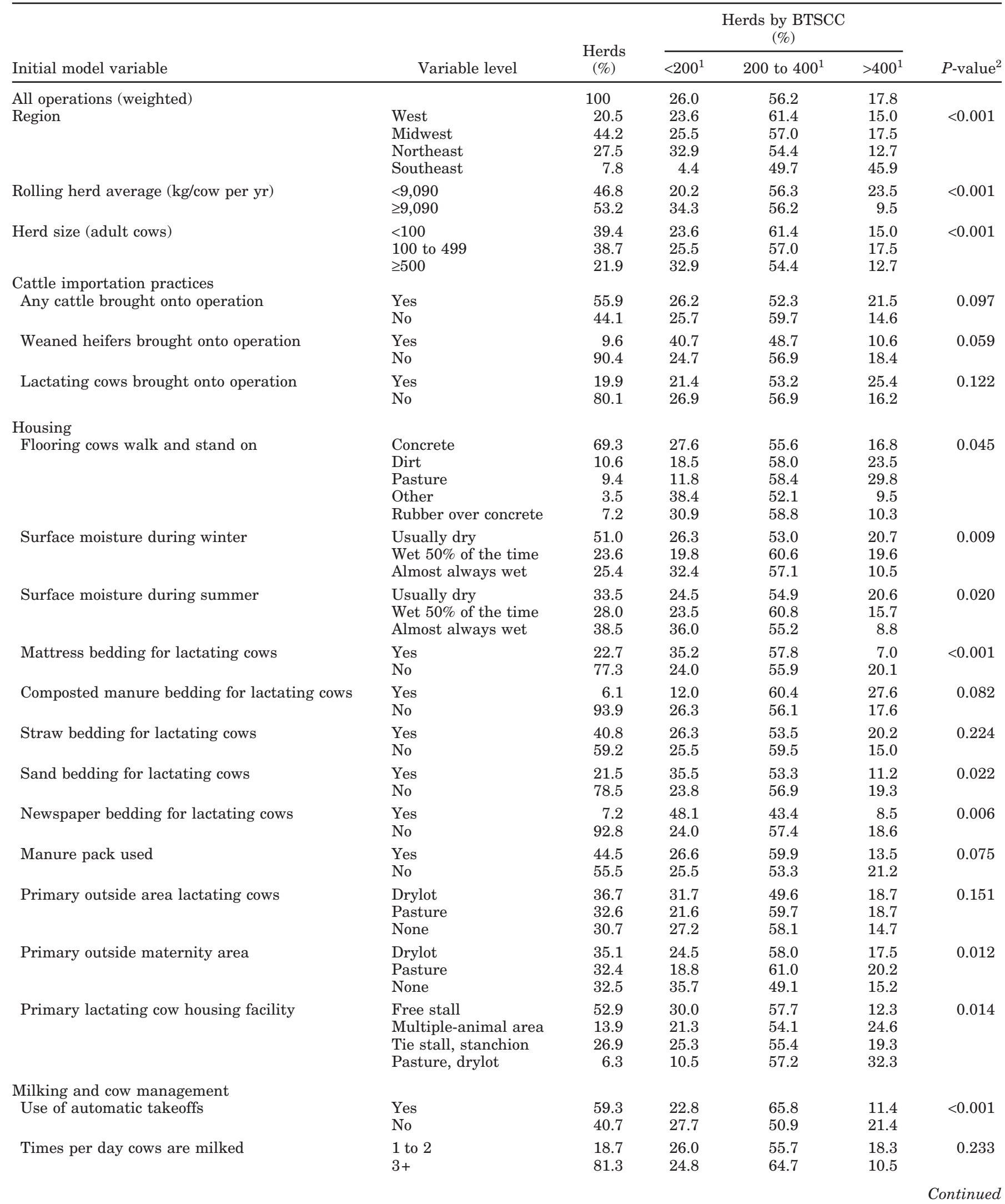


Table 1 (Continued). Herd management variables associated $(P<0.25)$ with bulk tank SCC (BTSCC) by univariate analysis of data from 1,013 dairies in 21 states

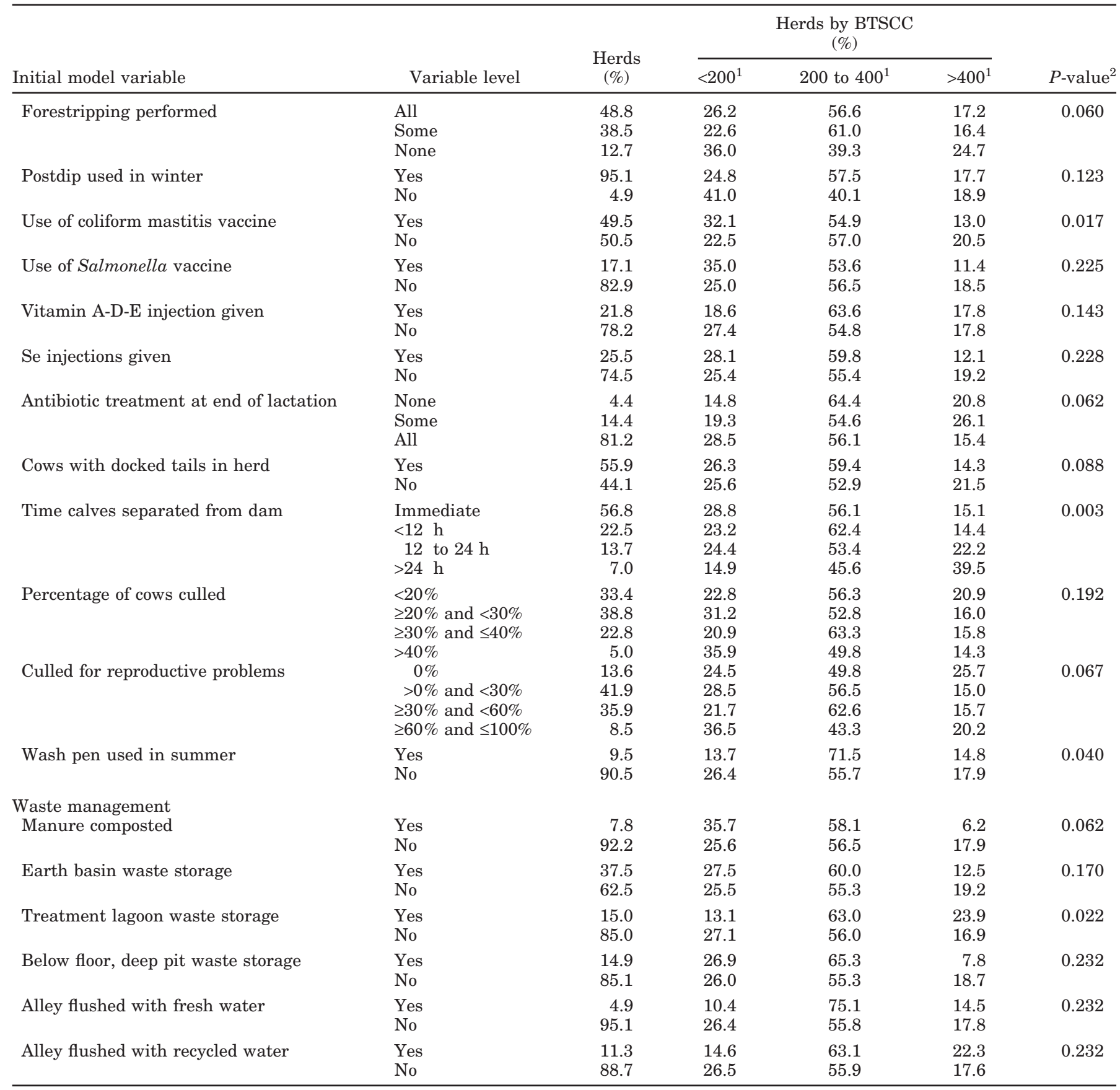

${ }^{1}$ Bulk tank SCC $(\times 1,000$ cells $/ \mathrm{mL})$ category.

${ }^{2}$ Weighted univariate log-likelihood $\chi^{2}$.

BTSCC $(P=0.082)$. The reported primary outside maternity area was evenly distributed among drylot, pasture, or no primary outside maternity area and was associated with BTSCC ( $P=0.012$; Table 1$)$. The primary lactating cow housing facility reported by operations was associated with BTSCC $(P=0.014$; Table 1$)$.
Free stall and tie stall or stanchion housing was reported by 52.9 and $26.9 \%$ of operations, respectively.

Numerous cow management variables were associated with BTSCC. The use of automatic takeoffs was reported by $59.3 \%$ of operations and was associated with a lower BTSCC $(P<0.001)$. Forestripping of all, 
Table 2. Results of principal components cluster analysis of herd management variables significant via weighted univariate screening

\begin{tabular}{|c|c|c|c|}
\hline Cluster & $\begin{array}{l}\text { Proportion } \\
\text { of variation }^{\text {explained }^{1}}\end{array}$ & Variable $^{2}$ & $1-\mathrm{R}^{2}$ ratio $^{3}$ \\
\hline 1 & 0.5446 & $\begin{array}{l}\text { Surface moisture during winter } \\
\text { Surface moisture during summer } \\
\text { Use of automatic takeoffs } \\
\text { Earth basin waste storage }\end{array}$ & $\begin{array}{l}0.294 \\
0.349 \\
0.639 \\
0.743\end{array}$ \\
\hline 2 & 0.4063 & $\begin{array}{l}\text { Composted manure used for bedding } \\
\text { Recycled water used to flush alley } \\
\text { Wash pen used during summer } \\
\text { Treatment lagoon waste storage } \\
\text { Manure is composted } \\
\text { Fresh water used to flush alley }\end{array}$ & $\begin{array}{l}0.460 \\
0.465 \\
0.569 \\
0.605 \\
0.784 \\
0.806\end{array}$ \\
\hline 3 & 0.5241 & $\begin{array}{l}\text { Any cattle brought onto operation } \\
\text { Lactating cows brought onto operation } \\
\text { Weaned heifers brought onto operation }\end{array}$ & $\begin{array}{l}0.288 \\
0.456 \\
0.703\end{array}$ \\
\hline 4 & 0.7391 & $\begin{array}{l}\text { Vitamin } \mathrm{A}, \mathrm{D} \text {, and } \mathrm{E} \text { injections given } \\
\text { Se injections given }\end{array}$ & $\begin{array}{l}0.273 \\
0.281\end{array}$ \\
\hline 5 & 0.2899 & $\begin{array}{l}\text { Straw used for bedding } \\
\text { Newspaper used for bedding } \\
\text { Sand used for bedding } \\
\text { Culled for reproductive problems }\end{array}$ & $\begin{array}{l}0.539 \\
0.657 \\
0.795 \\
0.909\end{array}$ \\
\hline 6 & 0.4040 & $\begin{array}{l}\text { Use of coliform mastitis vaccine } \\
\text { Times per day cows are milked } \\
\text { Use of Salmonella vaccine } \\
\text { Time calves separated from dam }\end{array}$ & $\begin{array}{l}0.485 \\
0.616 \\
0.681 \\
0.774\end{array}$ \\
\hline 7 & 0.3776 & $\begin{array}{l}\text { Mattresses used for bedding } \\
\text { Cows with docked tails in herd } \\
\text { Manure pack used } \\
\text { Below floor and deep pit waste storage }\end{array}$ & $\begin{array}{l}0.517 \\
0.656 \\
0.719 \\
0.760\end{array}$ \\
\hline 8 & 0.4144 & $\begin{array}{l}\text { Forestripping performed } \\
\text { Percentage of cows culled } \\
\text { Antibiotic treatment at end of lactation }\end{array}$ & $\begin{array}{l}0.507 \\
0.649 \\
0.663\end{array}$ \\
\hline 9 & 1.0000 & Postdipping performed during winter & 0.000 \\
\hline
\end{tabular}

${ }^{1}$ Proportion of variation explained by a cluster indicates how well the cluster represents its constituent variables.

${ }^{2}$ The first variable listed in a cluster had the lowest $1-R^{2}$ ratio, indicating it was most typical of the cluster and was submitted for ordinal logistic regression modeling.

${ }^{3}$ The $1-R^{2}$ ratio gives the ratio of $1-R^{2}$ of a variable's own cluster to $1-R^{2}$ of the variable's next closest cluster. A variable closely correlated with more than 1 cluster has a ratio close to 1 , but a variable typical of its cluster has a ratio close to 0 .

some (i.e., mastitic and fresh cows), or none of the cows was reported by $48.8,38.5$, and $12.7 \%$ of operations, respectively, and tended toward an association with BTSCC $(P=0.06$; Table 1$)$. Use of a coliform mastitis vaccine was reported by $49.5 \%$ of operations and was associated with a lower BTSCC $(P=0.017)$. All, some, and none of the cows received prophylactic antibiotic treatment at the end of lactation [dry cow therapy (DCT)] on $81.2,14.4$, and $4.4 \%$ of operations, respectively. There tended to be an association between DCT and BTSCC $(P=0.062$; Table 1$)$. Fifty-six percent of operations reported having some cows with docked tails, and there tended to be an association with a lower BTSCC $(P=0.087)$.

Principal components cluster analysis of 31 ordinal variables resulted in 9 clusters that explained $46 \%$ of the variation of those variables (Table 2). The low proportion of variation explained by many clusters indicated that there was heterogeneity among variables within those clusters. Cluster 2 mostly represented waste management variables; cluster 3 represented cattle importation practices; cluster 4 described supplement administration; and all but 1 variable in cluster 5 dealt with lactating cow bedding type. Cluster 9 contained only 1 variable: postmilking teat dipping (PMTD) practices in winter. The remaining clusters were not easily categorized based on their constituent variables.

Backward elimination ordinal logistic regression modeling resulted in a final model containing 5 variables (Table 3). To test the assumption of the final model that the effect of a variable was the same comparing 
Table 3. Final logistic regression model describing the association between management variables and producer-reported bulk tank SCC level

\begin{tabular}{|c|c|c|c|c|}
\hline Variable & Level & $\begin{array}{l}\text { Odds } \\
\text { ratio }^{1}\end{array}$ & $\begin{array}{l}95 \% \text { odds } \\
\text { ratio } \\
\text { confidence } \\
\text { interval }\end{array}$ & $\begin{array}{c}\text { Final } \\
\text { model } \\
P \text {-value }\end{array}$ \\
\hline & $\begin{array}{l}\text { Intercept } 1 \\
\text { Intercept } 2\end{array}$ & $\begin{array}{r}0.65 \\
11.08\end{array}$ & $\begin{array}{l}0.32 \text { to } 1.35 \\
5.33 \text { to } 23.04\end{array}$ & $\begin{array}{l}<0.001 \\
<0.001\end{array}$ \\
\hline Region & $\begin{array}{l}\text { West } \\
\text { Midwest } \\
\text { Northeast } \\
\text { Southeast }\end{array}$ & $\begin{array}{l}0.19 \\
0.20 \\
0.13\end{array}$ & $\begin{array}{l}0.09 \text { to } 0.38 \\
0.11 \text { to } 0.38 \\
0.06 \text { to } 0.26 \\
\text { Referent }\end{array}$ & $<0.001$ \\
\hline Rolling herd average (kg/cow per yr) & $\begin{array}{l}<9,090 \\
\geq 9,090\end{array}$ & 2.15 & $\begin{array}{l}1.50 \text { to } 3.08 \\
\text { Referent }\end{array}$ & $<0.001$ \\
\hline Vitamin $\mathrm{A}, \mathrm{D}$, and $\mathrm{E}$ injection & $\begin{array}{l}\text { Used } \\
\text { Not used }\end{array}$ & 1.58 & $\begin{array}{l}1.05 \text { to } 2.35 \\
\text { Referent }\end{array}$ & 0.027 \\
\hline Composted manure bedding & $\begin{array}{l}\text { Used } \\
\text { Not used }\end{array}$ & 2.88 & $\begin{array}{l}1.27 \text { to } 6.55 \\
\text { Referent }\end{array}$ & 0.012 \\
\hline Coliform mastitis vaccine & $\begin{array}{l}\text { Not used } \\
\text { Used }\end{array}$ & 1.65 & $\begin{array}{l}1.14 \text { to } 2.40 \\
\text { Referent }\end{array}$ & 0.008 \\
\hline
\end{tabular}

${ }^{1}$ Odds of having a higher bulk tank SCC level.

the lowest BTSCC group with the middle group as comparing the middle with the highest was valid; the final model was run without weighting in SAS. The score test for the proportional odds assumption was not significant $(P=0.08)$, suggesting that the slope coefficients were equal across the cumulative logits for each predictor variable. This supported the proportional odds assumption in our final model.

The odds of an operation from the West, Midwest, and Northeast having a high BTSCC were lower than those from the Southeast (Table 3). The odds of a higher BTSCC were 2.15 (1.50 to 3.08) times greater for operations with a RHA milk production $<9,090 \mathrm{~kg} / \mathrm{cow}$ per year compared with those with $\geq 9,090 \mathrm{~kg} / \mathrm{cow}$ per year. The odds of a higher BTSCC were 1.58 (1.05 to 2.35) times greater for operations that reported using vitamin $\mathrm{A}, \mathrm{D}$, and $\mathrm{E}$ injection. The odds of having a higher BTSCC were 2.88 (1.27 to 6.55) times greater for operations using composted manure compared with those not using composted manure. Finally, operations not using a coliform mastitis vaccine were 1.65 (1.14 to 2.40) times more likely to have a higher BTSCC than those using one.

\section{DISCUSSION}

Cross-sectional studies based on questionnaires of management practices and measures of BTSCC are common (Hutton et al., 1990; Goodger et al., 1993; Faye et al., 1997; Barkema et al., 1998; Rodrigues and Ruegg, 2005). These studies shed light on associations between management practices and the level of SCC in the bulk tank, a proxy for udder health in the herd. They suffer, however, from several limitations including producer- reporting bias, bias due to clustering of management practices, and the fact that differences in managerial skills are not represented in questions that merely ask if practices are used.

To decrease the potential for producer-reporting bias, the management questionnaire used in this study was standardized and pretested on multiple operations before being administered. Furthermore, the questionnaire was administered by trained personnel. Additionally, producer-reported BTSCC was compared with the BTSCC of a single bulk tank milk sample collected at the time of questionnaire administration on a subset of operations. Of the 741 operations in which BTSCC were measured, only $17.3 \%$ reported a category BTSCC lower than the measured BTSCC. These findings suggest that most producers did not underestimate their BTSCC, and the reported BTSCC is an accurate representation for these operations.

When there are many independent variables in a study, the objective of logistic model building should be to construct a parsimonious model that is numerically stable and can be readily generalized (Hosmer and Lemeshow, 2000). Too many variables in the model can result in overfitting and produce unstable estimates. We performed oblique principal components cluster analysis and selected the variable most representative (lowest $1-R^{2}$ ) of each of the 9 resulting clusters for model building (Nelson, 2001). This was done to achieve variable reduction and reduce the potential for bias associated with clustering of management practices within the final model. From a dairy management point of view, the variables within some clusters appeared to be grouped logically; however, it is important to realize this is not a necessary result of the cluster analysis. 
A limitation of this study was the fact that potential differences in managerial skills were not identified by the questionnaire, which only asks if particular management practices were used. The quality and consistency of management practice application was not evaluated in this study and may confound associations between specific management practices and BTSCC. Technical skill, precision, and attention to detail in the implementation of a management practice likely have an important effect on associations with BTSCC. Barkema et al. (1999) specifically addressed this issue by grouping herds based on management style questions. In that study, herds with a "quick and dirty" management style had a higher BTSCC than herds with a "clean and accurate" style. This categorization related to a difference between groups such that the group that worked more precisely rather than quickly had better hygienic conditions and lower BTSCC. Hutton et al. (1990) found the majority of low-BTSCC ( $\leq 283,000$ cells/ $\mathrm{mL}$ ) herds and high-BTSCC (>283,000 cells $/ \mathrm{mL}$ ) herds implemented DCT; however, it was observed that significantly more low herds (96\%) routinely disinfected teat ends before DCT than high herds (67\%). Wilson et al. (1997) found no association between DCT or PMTD and BTSCC, and the authors suggested wide adoption of the practices $(>80 \%)$ by herds in the study reduced the likelihood they would explain BTSCC differences among herds. In the current study, the postdipping performed during winter variable was in its own cluster, and DCT was in cluster 8 with the percentage of cows culled and forestripping variables. Neither the indicator variable from cluster 8 nor the PMTD variable was included in the final model. As with previous reports, a high proportion of operations in this study reported dry treating all cows (81\%) and performing PMTD (75\%). Furthermore, differences in quality of application of these practices were not assessed and may have confounded associations with BTSCC. Assessing managerial style or quality of management practice application in future studies may provide a better understanding of management factors influencing BTSCC.

A direct association between the prevalence of Streptococcus agalactiae and Staphylococcus aureus and elevated BTSCC has been identified (Wilson et al., 1997). Hutton et al. (1990) found no difference between low $(\leq 283,000$ cells $/ \mathrm{mL})$ herds and high $(>283,000$ cells $/ \mathrm{mL})$ herds in the prevalence of Strep. agalactiae (0.3 and $0.7 \%$ respectively) but identified a higher prevalence of Staph. aureus IMI in high herds $(14.6 \%)$ compared with low herds $(3.0 \%)$. Unfortunately, data on the prevalence of contagious mastitis pathogens was not available for inclusion in this study and may serve to confound associations between BTSCC and the management prac- tices evaluated. Future studies evaluating the association between management practices and BTSCC should include some indication of the prevalence of contagious mastitis pathogens.

Previously, Hutton et al. (1990) identified an association between environmental factors and BTSCC. In that study, maternity cow area was significantly drier, and fewer herds had standing water in the pastures of lowBTSCC vs. high-BTSCC herds. Similarly, Barkema et al. (1998) showed that greater attention to dry cow hygiene and nutrition was associated with herds with lower BTSCC. Khaitsa et al. (2000) also found that dry cow management factors and housing of dry cows was associated with BTSCC. In the present study, the primary outside maternity area was univariately associated with BTSCC. Considering that 4 to 5 times more environmental IMI occur during the dry period than during lactation, taken together, these data suggest that environmental mastitis pathogens may be more influential on BTSCC than previously recognized. This may be especially true in herds that have successfully controlled contagious mastitis pathogens. This notion is further supported by the results of this study showing an association between a higher BTSCC and operations that did not use a coliform mastitis vaccine and the association between housing type and BTSCC. These associations were not very strong; however, they may have been confounded by contagious mastitis prevalence. Future studies focused on herds with a low prevalence of contagious mastitis pathogens may identify stronger associations between BTSCC and management factors that reduce exposure to environmental mastitis pathogens.

Further supporting the potentially important influence of environmental mastitis pathogens was the fact that reported use of specific bedding types was associated with BTSCC. In the univariate analysis mattress, sand and newspaper use was associated with a lower BTSCC. In the final multivariate model, the odds of a higher BTSCC were greater in operations using composted manure than those that did not. When interpreting these results, it is important to realize that the absence of a variable from the final model does not imply that there is not a significant association with the outcome, such as demonstrated by the univariate analysis. The multivariate model assesses the importance of variables given the presence of other variables in the model, and this may yield a different result than the univariate analysis.

The results of this and previous studies have identified associations between environmental mastitis pathogen risk factors (dry and lactating cow housing, bedding and coliform mastitis vaccine use) and BTSCC. This association is likely related to management style 
on the operation as described above and maintenance of a clean, dry environment for both lactating and dry cows. None the less, failure of management to provide clean, dry housing conditions increases risk of environmental pathogen IMI, which may result in higher BTSCC. This is particularly true as more herds effectively control contagious mastitis pathogens and the prevalence of chronic Escherichia coli infections rises (Bradley and Green, 2001).

\section{CONCLUSIONS}

This study identified associations between management practices and BTSCC in US dairy herds. Variables such as RHA, region, and herd size were associated with BTSCC level and are likely catch-all variables that reflect general trends in management. The other significant variables dealt with housing, bedding used, and coliform mastitis vaccine use and suggest the effect of environmental mastitis pathogens may be more influential on BTSCC than previously thought. Future studies of the association between management factors and BTSCC should include evaluation of managerial style or quality of management practice application as well as herd prevalence of contagious mastitis pathogens.

\section{REFERENCES}

Ali, A. E., A. T. Andrews, and G. C. Cheeseman. 1980. Influence of elevated somatic cell count on casein distribution and cheesemaking. J. Dairy Res. 47:393-400.

Barkema, H. W., Y. H. Schukken, T. J. G. M. Lam, M. J. Beiboer, G. Benedictus, and A. Brand. 1998. Management practices associated with low, medium, and high somatic cell counts in bulk milk. J. Dairy Sci. 81:1917-1927.

Barkema, H. W., J. D. Van der Ploeg, Y. H. Schukken, T. J. Lam, G. Benedictus, and A. Brand. 1999. Management style and its association with bulk milk somatic cell count and incidence rate of clinical mastitis. J. Dairy Sci. 82:1655-1663.
Bartlett, P. C., G. Y. Miller, S. E. Lance, and L. E. Heider. 1992. Environmental and managerial determinants of somatic cell counts and clinical mastitis incidence in Ohio dairy herds. Prev. Vet. Med. 14:195-207.

Bradley, A. J., and M. J. Green. 2001. Adaptation of Escherichia coli to the bovine mammary gland. J. Clin. Microbiol. 39:1845-1849.

Erskine, R. J., R. J. Eberhart, L. J. Hutchinson, S. B. Spencer, and M. A. Campbell. 1987. Herd management and prevalence of mastitis in dairy herds with high and low somatic cell counts. J. Am. Vet. Med. Assoc. 190:1411-1416.

Faye, B., F. Lescourret, N. Dorr, E. Tillard, B. MacDermott, and J. McDermott. 1997. Interrelationships between herd management practices and udder health status using canonical correspondence analysis. Prev. Vet. Med. 32:171-192.

Goodger, W. J., T. Farver, J. Pelletier, P. Johnson, G. de Snayer, and J. Galland. 1993. The association of milking management practices with bulk tank somatic cell counts. Prev. Vet. Med. 15:235-251.

Hosmer, D. W., and L. Lemeshow. 2000. Applied Logistic Regression. 2nd ed. John Wiley and Sons Inc., New York, NY.

Hutton, C. T., L. K. Fox, and D. D. Hancock. 1990. Mastitis control practices: Differences between herds with high and low milk SCC. J. Dairy Sci. 73:1135-1143.

Khaitsa, M. L., T. E. Wittum, K. L. Smith, J. L. Henderson, and K. H. Hoblet. 2000. Herd characteristics and management practices associated with bulk-tank somatic cell counts in herds in official Dairy Herd Improvement Association programs in Ohio. Am. J. Vet. Res. 61:1092-1098.

Ma, Y., C. Ryan, D. M. Barbano, D. M. Galton, M. A. Rudan, and K. J. Boor. 1999. Effects of somatic cell count on quality and shelflife of pasteurized fluid milk. J. Dairy Sci. 83:264-274.

Nelson, B. D. 2001. Variable reduction for modeling using PROC VARCLUS. Paper 261-26 in 26th Annu. SAS Users Group Int. Proc., Long Beach, CA. http://www2.sas.com/proceedings/sugi26/ p261-26.pdf Accessed June 13, 2007.

Norman, H. D., R. H. Miller, J. R. Wright, and G. R. Wiggans. 2000. Herd and state means for somatic cell count from dairy herd improvement. J. Dairy Sci. 83:2782-2788.

Ott, S. L., and P. R. Novak. 2001. Association of herd productivity and bulk-tank somatic cell counts in US dairy herds in 1996. J. Am. Vet. Med. Assoc. 218:1325-1330.

Rodrigues, A. C. O., and P. L. Ruegg. 2005. Actions and outcomes of Wisconsin dairy farms completing milk quality teams. J. Dairy Sci. 88:2672-2680.

Wilson, D. J., H. H. Das, R. N. Gonzalez, and P. M. Sears. 1997. Association between management practices, dairy herd characteristics, and somatic cell count of bulk tank milk. J. Am. Vet. Med. Assoc. 210:1466-1469, 